Citation: Cohen J. S. (2021) History of Research on Antisense Oligonucleotide Analogs. Substantia. Substantia 5(1) : 9-25. doi: 10.36253/Substantia-964

Received: Jun 09, 2020

Revised: Aug 09, 2020

Just Accepted Online: Aug 11, 2020

Published: Mar 01, 2021

Copyright: (c) 2021 Cohen J. S.. This is an open access, peer-reviewed article published by Firenze University Press (http://www.fupress.com/substantia) and distributed under the terms of the Creative Commons Attribution License, which permits unrestricted use, distribution, and reproduction in any medium, provided the original author and source are credited.

Data Availability Statement: All relevant data are within the paper and its Supporting Information files.

Competing Interests: The Author(s) declare(s) no conflict of interest.
Feature Articles

\section{History of Research on Antisense Oligonucleotide Analogs}

\author{
JACK S. COHEN \\ Chemistry Department, Ben Gurion University, Be'er Sheva, Israel \\ E-mail: cohenjk@post.bgu.ac.il
}

\begin{abstract}
In the search for novel therapeutics, antisense oligonucleotide (ASO) analogs have been a major focus of research for over 40 years. They use the antisense strategy, namely they have a nucleic acid base sequence that is complementary to a portion of a specific mRNA that is produced in the cell, or to a viral RNA, in order to selectively inhibit gene expression. Oligonucleotides need to be chemically modified to stabilize them against hydrolysis by endogenous nucleases. Until now several phosphorothioate (PS) oligonucleotide analogs have been approved by the FDA for human use. This article seeks to provide a history of this subject to date.
\end{abstract}

Keywords: Antisense, Oligonucleotide, Analogs, Therapeutic, RNA.

\section{INTRODUCTION}

The basic premise of the antisense approach to therapy is that since most human diseases are genetic in origin, it is necessary to use a genetic means to cure them. This includes cancer and infectious diseases, being the insertion of bacterial or viral genes into cells. Antisense depends on the intervention of information-containing drugs in the form of synthetic oligonucleotides to disrupt the flow of information transfer from DNA to RNA to protein. ${ }^{1}$ Since DNA is highly protected, the process of transcription from DNA to mRNA is more difficult to target, ${ }^{2}$ so the process of protein biosynthesis is the easier to target, hence antisense is a form of translation arrest in which the mRNA is targeted (Figure 1). Whereas usual drugs bind strongly to a protein active site and inhibit its action, the antisense approach is intended to prevent expression of the same protein by blocking its synthesis at the basic molecular level using Watson-Crick base pairing.

Antisense is a term that was introduced following the description of the double helical structure of DNA by Watson and Crick, ${ }^{3}$ the sense strand being the one that is expressed into protein and the antisense strand being its unexpressed complement. The first published use of an oligonucleotide as an antisense inhibitor was by Paul Zamecnik and Mary L. Stephenson against Rous sarcoma virus in 1978. ${ }^{4,5}$ This was before the advent of DNA synthesizers, so they had a natural phosphodiester (PO) 13-mer oligo ${ }^{6}$ synthesized 


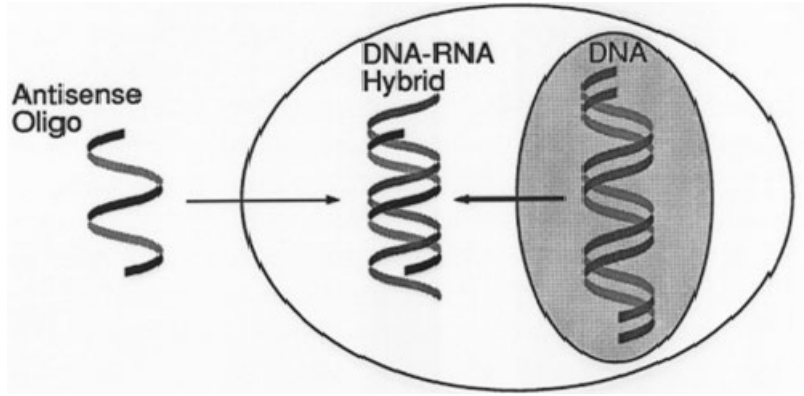

Figure 1. Schematic showing translation arrest by an antisense oligo binding to a cellular mRNA.

manually for them that was complementary to a 3 ' and 5 'reiterated terminal region, and they found it inhibited virus production. The use of a natural PO oligo no doubt resulted in hydrolysis to some extent by nucleases in the system. ${ }^{7}$ Other work was reported on this antisense approach using specific sequence PO oligos. ${ }^{8,9}$ Zamecnik was awarded the National Medal of Science in 1991 for his work on antisense among other things.

This story began for me in $1986,{ }^{10}$ when a paper appeared in Biochemistry reporting the use of a chemically modified antisense oligonucleotide (ASO) analog inhibiting stomatitis virus infection from Paul Ts'o and Paul Miller at Johns Hopkins University. ${ }^{11}$ They used a methylphosphonate (PM) analog (Figure 2) to stabilize the oligo against endogenous nucleases in the cell. I was aware of this work from a symposium we had both attended in Jerusalem the previous year ${ }^{12}$ and from their previous published work. ${ }^{13}$ Note however that their use of 9-mers meant that they were unlikely to have bound very effectively as a duplex with the target RNA.

The potential of this approach against HIV and cancer was clear, and so because of my background and experience in DNA chemistry, ${ }^{14}$ I was assigned to develop this approach in the NCI by my Lab and Division Chiefs. ${ }^{15}$ I began a collaboration with my colleague Gerald Zon, Bureau of Biologics, FDA, since he was b-testing a prototype Applied Biosystems automated DNA synthesizer in his lab. ${ }^{16,17}$

Serendipitously, Zon and his colleagues were synthesizing phosphorothioate (PS) analogs (Figure 2) of oligos to identify signals in the ${ }^{31} \mathrm{P}$ NMR spectrum..$^{18}$ Phosphorothioate poly-ribonucleotides had been described by Eckstein and co-workers, ${ }^{19}$ and their resistance to hydrolysis by nucleases had been noted, ${ }^{20,21}$ but no-one before had synthesized specific sequence PS oligomers for a therapeutic application. We tested several PS oligos targeted against the rev gene mRNA of HIV in collaboration with Sam Broder, Head of the Oncology Program at NCI, using the PM and PS analogs with the natural

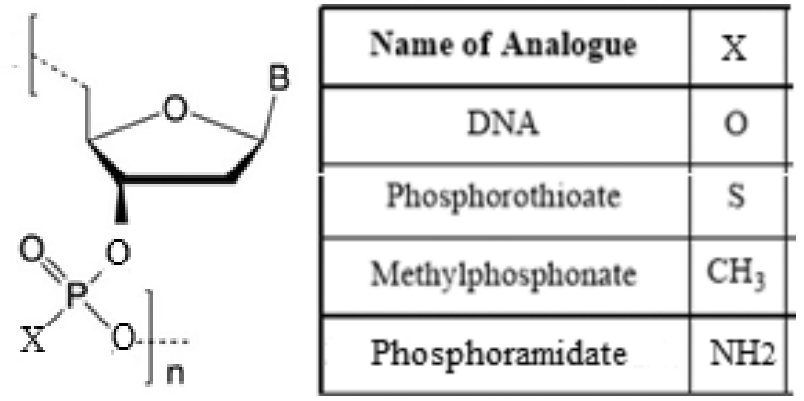

Figure 2. DNA analogs based on minor substituents of the canonical structure.

phosphate (PO) oligos as controls. The rev gene (also known as art/trs) was chosen because it produces the gag protein that can easily be quantified. We used 28-mers since according to the calculations of Hélène and Toulmé this should reduce the probability to a single target sequence in the human genome and would be long enough to duplex. ${ }^{22}$ This had consequences since at that length the PM oligos, which are uncharged and hydrophobic, were virtually insoluble and gave very low yields.

By contrast, the PO and PS analogs are charged and are water soluble. However, at first the yield of PS analog was low due to the inefficiency of the sulfurization reaction $^{23}$ compared to the usual oxidation reaction. ${ }^{24,25}$ We were able to increase the yield using a different solvent. ${ }^{26}$ The oligomers were tested in an HIV assay and the PS oligomers showed excellent inhibition against the rev gene, but none with the PM oligos or the PO oligo controls. ${ }^{27}$ However, disturbingly we also found inhibition by the control sequence PS compounds, as well as PS homo-oligomers. This led to further research using a more appropriate assay system using chronically infected cells that gave a pure sequence-dependent antisense inhibition, with the same controls as before (Figure 3). ${ }^{28}$

Zon and his collaborators carried out a comparative study of inhibition of the chloramphenicol acetyltransferase (CAT) gene in a plasmid by various oligo analogs (phosphodiester, methylphosphonate, alkyltriester and phosphorothioate) and found that the PS analog was the most effective. ${ }^{29}$ Zamecnik and his colleagues also applied PS and phosphoramidate oligo analogs to HIV. ${ }^{30}$ We also compared the inhibition by PS oligos against the gag, pol and rev genes of HIV ${ }^{31}$ and we also extended the use of PS oligos against other viruses. ${ }^{32}$ We also expanded our work with PS oligos to the selective inhibition of oncogenes, c-myc in hematopoietic cells in culture by liposome fusion ${ }^{33}$ and $b c l-2$ in leukemic cells. ${ }^{34}$

After these initial results were reported there was an immediate reaction. ${ }^{35}$ Several companies were established $^{36}$ (Table 1), with billions of dollars of investment, 


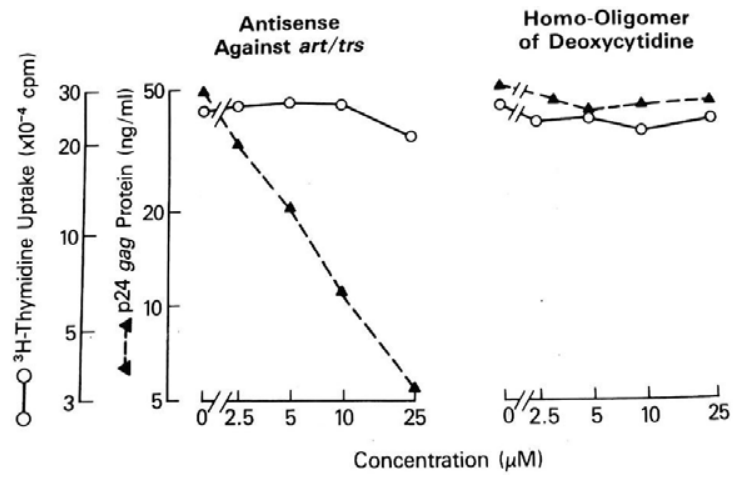

Figure 3. Sequence-specific inhibition of HIV p24 gag protein expression after 5 days in culture supernatant by the antisense phosphorothioate 28 mer against rev (5'-dTCG TCG CGT TCT CCG CTT CCT GCC A) determined using a radioimmunoassay (left). Neither the normal oligo, the sense phosphorothioate nor the homo-oligomer $\mathrm{S}-\mathrm{dC}_{28}$ (right) had any inhibitory effect. ${ }^{28}$

to exploit the finding of stable PS oligos as therapeutic agents, which was patented by NIH. ${ }^{37}$ Several of the original companies were subsequently taken over by larger companies and also diversified their products to other than antisense compounds.

I organized one of first conferences on this subject entitled "Oligodeoxynucleotides as Antisense Inhibitors of Gene Expression: Therapeutic Implications," that was sponsored by NCI and NIAID and held in Rockville, MD, on June 18-21, 1989. ${ }^{38}$ About 300 people attended, including most of those then active in the field. Many companies supported the conference and the dinner speaker was Michael Riordan of Gilead Sciences, whose subject was "Oligos: a commercial proposition." Other early conferences on this topic were held in the UK (Cambridge, organized by Dan Brown, 1987), France (Les Arc, organized by Jean-Jacques Toulmé, 1988), Russia (Akademgorodok, organized by Valentin Vlassov, 1988). ${ }^{39}$

If one searches the scientific literature (using CAS SciFinder) for "antisense AND oligonucleotide" there are some 43,000 hits, with a gradual increase from 1987 (15 hits) to $2001(3,249)$ and then a gradual decline to 2019 (1,086) (Figure 4). Explaining this histogram is one aspect of the function of this article. Clearly it would be impossible to do justice to all these many articles, reviews $(4,837)$ and other publications on this topic. However, it is the responsibility of the author to try to discern trends in this morass of data.

In 1989 we published the first volume on this subject, entitled "Oligodeoxynucleotides: Antisense Inhibitors of Gene Expression," 41 which contained chapters from all the leading researchers in the field. This is an
Table 1. Companies engaged in antisense and DNA therapeutic R\&D.*

\begin{tabular}{|c|c|c|}
\hline Company & Location & Comment \\
\hline Akcea Therapeutics & Boston MA & Owned by Ionis \\
\hline Biogen & Cambridge MA & \\
\hline Codex & San Diego CA & \\
\hline Dynacure & Illkirch, France & \\
\hline Dynavax Technologies & Emeryville CA & \\
\hline Genta Inc. & San Diego CA & \\
\hline Gilead Sciences & Foster City CA & Founded 1987 \\
\hline $\begin{array}{l}\text { Helix } \\
\text { Naonotechnologies }\end{array}$ & Cambridge MA & \\
\hline Hybridon & Worcester MA & Acquired by Idera in 2004 \\
\hline Ionis Pharmaceuticals & Carlsbad CA & Originally ISIS Pharma \\
\hline NapaJen Pharma & Burlingame CA & Japanese company \\
\hline Pharmagenics & Allendale NJ & $\begin{array}{l}\text { Acquired by Genzyme in } \\
1997\end{array}$ \\
\hline Procarta Biosystems & Norwich UK & \\
\hline $\begin{array}{l}\text { Ranger } \\
\text { Biotechnologies }\end{array}$ & Funen Denmark & \\
\hline RogCon Biosciences & San Diego CA & \\
\hline $\begin{array}{l}\text { Secarna } \\
\text { Pharmaceuticals }\end{array}$ & $\begin{array}{l}\text { Martinsreid } \\
\text { Germany }\end{array}$ & \\
\hline Sterna Biologicals & $\begin{array}{l}\text { Marburg } \\
\text { Germany }\end{array}$ & \\
\hline Stoke Therapeutics & Bedford MA & \\
\hline $\begin{array}{l}\text { Triplex } \\
\text { Pharmaceuticals }\end{array}$ & Woodlands TX & $\begin{array}{c}\text { Acquired by Argus in } \\
1995\end{array}$ \\
\hline Zata Pharmaceuticals & Worcester MA & \\
\hline
\end{tabular}

* This is not a complete list.

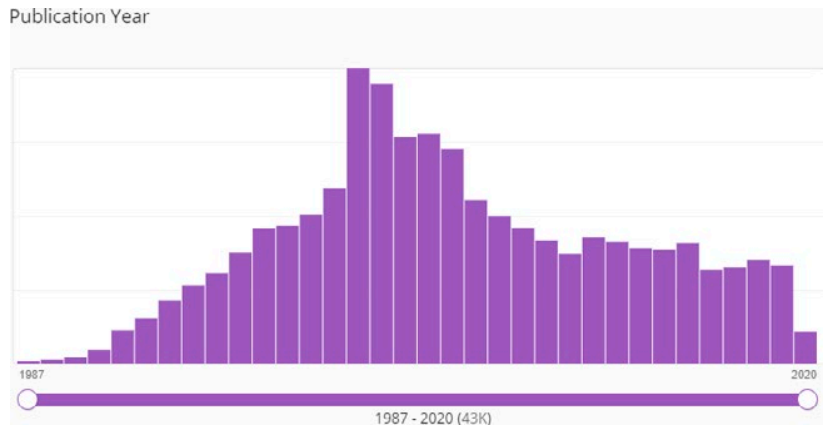

Figure 4. Number of publications per year for the literature search "antisense AND oliogonucleotides." The discovery of the PS analog of oligos as a stable (slowly hydrolysable) and water-soluble (hydrophilic) alternative to the natural PO compounds, made the antisense oligo approach feasible for human therapy, ${ }^{40}$ and led to the initial increase in published work on this subject. 
Table 2. First Generation Oligonucleotide Analogs.

\begin{tabular}{|c|c|c|c|}
\hline Analog & Designation & Structure & Reference \\
\hline Phosphate & $\mathrm{PO}$ & $(\mathrm{RO})\left(\mathrm{R}^{\prime} \mathrm{O}\right)(\mathrm{HO})-\mathrm{P}=\mathrm{O}$ & Zamecnik et al., $1978^{4}$ \\
\hline Methylphosphonate & PM & $(\mathrm{RO})\left(\mathrm{R}^{\prime} \mathrm{O}\right)(\mathrm{CH} 3)-\mathrm{P}=\mathrm{O}$ & $\begin{array}{l}\text { Agris et al., } 1986^{11} \\
\text { Tidd et al. } 1988^{47}\end{array}$ \\
\hline Phosphorothioate & PS & $(\mathrm{RO})\left(\mathrm{R}^{\prime} \mathrm{O}\right)(\mathrm{HO})-\mathrm{P}=\mathrm{S}$ & Matsukura et al,, $1987^{27}$ \\
\hline a-anomer & $\mathrm{a}-\mathrm{PO}$ & $i^{2}=$ & $\begin{array}{l}\text { Morvan et al., } 1987^{48} \\
\text { Rayner et al., } 1990^{49}\end{array}$ \\
\hline Phosphoroselenoate & PSe & $(\mathrm{RO})\left(\mathrm{R}^{\prime} \mathrm{O}\right)(\mathrm{HO})-\mathrm{P}=\mathrm{Se}$ & Mori et al., $1989^{50}$ \\
\hline Phosphotriesters & --- & $(\mathrm{RO})\left(\mathrm{R}^{\prime} \mathrm{O}\right)\left(\mathrm{R}^{\prime \prime} \mathrm{O}\right)-\mathrm{P}=\mathrm{O}$ & Miller et al., $1974^{51}$ \\
\hline Phosphorodithioate & PS2 & $(\mathrm{RO})\left(\mathrm{R}^{\prime} \mathrm{O}\right)(\mathrm{HS})-\mathrm{P}=\mathrm{S}$ & Jaroszewski et al., $1996^{52}$ \\
\hline Phosphoramidate & $\mathrm{PNH} 2$ & $(\mathrm{RO})\left(\mathrm{R}^{\prime} \mathrm{O}\right)-\mathrm{P}(\mathrm{O})-\mathrm{NH} 2$ & $\begin{array}{l}\text { Agrawal et al., } 1988^{30} \\
\text { Peyrotte et al. } 1996^{53}\end{array}$ \\
\hline
\end{tabular}

excellent summary of the state of affairs in this subject at that time. A series of alternative oligo analogs were described that have come to be called "first generation analogs." (Table 2) and note that they were mostly developed prior to 1990 .

Mixed alternating co-polymers, such as (PO-PS) $\mathrm{n}^{42}$ and (PM-PS)n, ${ }^{43}$ and end-protected analogs on natural PO oligos to protect against exonucleases ${ }^{44}$ were also described. Since the PS analog appeared at that time to be the best analog available for truly therapeutic purposes, many applications were made with them, including clinical trials and applications to the FDA for human use. ${ }^{45,46}$

\section{PROBLEMS WITH OLIGONUCLEOTIDE ANALOGS}

Several factors can mainly be blamed for the subsequent gradual decrease in published work on antisense oligo analogs after 2001 (Figure 4): first, problems that arose in the application of the PS and other ASO analogs as therapeutic agents, including: 1. cellular uptake; 2. non-sequence dependent effects; 3 . RNase $\mathrm{H}$ function; 4. cost of production; 5. primary, secondary and tertiary structure effects of oligos. The second cause of the reduction in interest in synthetic oligo analogs was the finding of endogenous antisense mechanisms within living cells, mainly so-called silencing RNA (siRNA). We will consider each of these factors as a part of the history of the development and application of ASO analogs.

\section{Cellular Uptake:}

Since the antisense mechanism occurs within the cell cytoplasm, it is essential that the putative inhibito- ry oligo must be able to enter the cell. This subject was considered early on in the history of antisense oligos. ${ }^{54}$ There are three means for cellular uptake of oligos: a. passive diffusion through the cell membrane; b. active transport via a specific membrane mechanism; and $c$. specific means of delivery, for example either encapsulating the oligo within liposomes, or attaching a membrane-active agent.

a. Passive diffusion: This usually only occurs for small hydrophobic compounds that dissolve in the membrane lipid bilayer, and it is unlikely for any oligomer, least of all a negatively charged one to be able to enter the cell by passive diffusion.

b. Active transport: A fluorescent label acridine was attached to the 5' end of oligos, in this case PS oligos in order to avoid cellular degradation, and the uptake into the cell was monitored over time. After 24 hours a punctate distribution (i.e discrete points of fluorescence) was observed, and this was taken to mean that uptake not only occurred, but that it was by the formation of vesicles within the cells (non-vesicular up-take would give a homogeneous distribution) (Figure 5). ${ }^{54}$

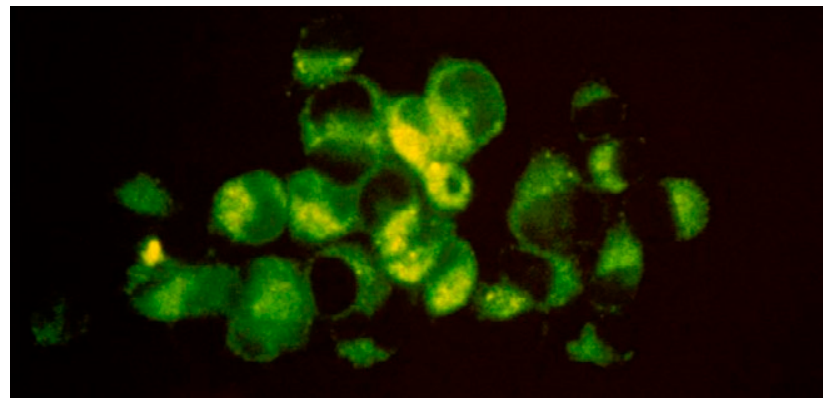

Figure 5. Photomicrograph showing punctate distribution of fluorescently labelled PS oligo within cells after 24 hrs exposure. ${ }^{54}$ 
c. Delivery mechanisms: The delivery of ASO into cells using liposomes was studied in detail by Yehezkel Barenholtz and co-workers, who investigated issues of sequence dependence, charge, size and composition of the liposomes, and studied comparative inhibition of the bcl-2 oncogene using different compositions of liposomes. ${ }^{55-57}$ The authors concluded that liposomes are an effective means of improved delivery of ASOs into cells. Other delivery mechanisms include linking the ASO with membrane-active peptides to enhance cellular uptake of ASOs, ${ }^{58}$ and binding to gold nanoparticles. ${ }^{59}$ This general subject has been reviewed. ${ }^{60,61}$

\section{Non-Sequence Dependent Effects}

Non-sequence dependent inhibition was observed with phosphorothioate oligomers in the first study carried out with HIV. ${ }^{27}$ In fact homo-oligomers of cytosine such as $\mathrm{S}-\mathrm{dC}_{18}$ were very efficient inhibitors of HIV replication. The mechanism of this inhibition was investigated in detail, which showed that the intact poly-anion was the active agent. ${ }^{62}$ These homo-polymers were also applied as inhibitors of other viruses. ${ }^{63,64}$ Although these non-sequence dependent effects in viruses were at first considered a potential problem for the application of PSoligos to cellular systems for the inhibition of oncogenes, this effect was never reported as a problem.

Another known problem is the antigenic effect of the sequence CpG in oligos, but this has been studied and can be avoided with substituents on the $\mathrm{C}$ base. ${ }^{65-67}$

\section{RNase H Function}

RNase $\mathrm{H}$ is an enzyme that specifically cleaves the RNA molecule in a DNA-RNA duplex. ${ }^{68,69}$ Therefore, it should enhance the effectiveness of an ASO relative to purely passive binding and inhibition. However, not all DNA analogs are substrates for RNase $\mathrm{H}^{70}$ The PS oligo analog is a substrate, ${ }^{71}$ but it depends on the number of PS groups present, if there are too many then the oligo can become inhibitory for RNase $\mathrm{H}$ action. ${ }^{72} \mathrm{On}$ the other hand, Summerton has argued that having an RNase $\mathrm{H}$-independent antisense function of morpholino ASOs is an advantage. ${ }^{73}$

\section{Cost of production}

It was understood from the start that ASOs are large molecules compared to usual drugs, and to produce them would cost much more. At first the cost per nucleotide for automated synthesis was prohibitive, but over time, savings in chemicals and methodology greatly reduced the cost ${ }^{74}$ so that now it is certainly affordable.

\section{Primary, secondary and tertiary effects of oligos}

Oligonucleotides are not always simply in a denatured conformation, but can form secondary and tertiary structures, such as hairpin loops and tetra-G complexes. How these can affect the inhibitory function of the intended ASO is not always easy to determine, but generally hairpin-loops have been proposed to be an aid to the protection of vulnerable oligos (mainly PO) against nucleases. ${ }^{75,76}$

\section{6. siRNA and its implications for ASO applications}

In 2006, the Nobel Prize in Physiology or Medicine was awarded jointly to Andrew Fire and Craig Mello for their discovery of RNA interference - gene silencing by RNA. ${ }^{77}$ It was realized that the large number of small RNA molecules, micro-RNAs, in the cell perform in effect an endogenous antisense function. ${ }^{78}$ This finding resulted in a competitive approach to the use of antisense oligonucleotides, namely the use of the so-called silencing or small interfering RNA, known as siRNA. ${ }^{79}$ It was soon realized that siRNA could be exploited either biologically or chemically, ${ }^{80}$ in the form of nuclease-protected ribo-oligonucleotide analogs, much like ASOs. Currently there are drugs based on RNAi being developed. ${ }^{81}$ It was also reported that there are synergistic effects between ASO analogs and siRNA inhibitors. ${ }^{82}$ There are problems with control of the siRNA approach, ${ }^{83}$ and the ASO methodology seems more "druggable." However, further consideration of this topic is beyond the scope of this article.

\section{SECOND GENERATION OLIGONUCLEOTIDE ANALOGS}

Because of the problems experienced with the PS analog, that was the first effective ASO developed, and because of the general desire to find more effective drug candidates, "second- generation analogs" were also subsequently developed, mostly after 1990 (Table 3). Here we will describe the most important of these and assess their potential as therapeutic agents relative to the firstgeneration ones, particularly the PS analog. 
Table 3. Second Generation Oligonucleotide Analogs.

\begin{tabular}{|c|c|c|c|}
\hline Name & Designation & Structure & References \\
\hline Acyclic derivatives & - & & Vandendriessche et al., $1993^{84}$ \\
\hline Peptide NA & PNA & & Egholm et al., $1992^{85}$ \\
\hline Locked NA & LNA & & Wengel et al., $1999^{86}$ \\
\hline Morpholino NA & - & & Summerton \& Weller, $1997^{87}$ \\
\hline 2'O-Me RNA & - & & Wagner et al., $1991^{88}$ \\
\hline 2'-Fluoro RNA & - & & Eckstein et al., $1991^{89}$ \\
\hline
\end{tabular}

\section{Acyclic nucleic acids}

There have been many attempts to prepare oligomers containing ring-opened furanoside, as shown in Table 3 (opened between $\mathrm{Cl}^{\prime}$ and $\mathrm{C} 4^{\prime}$ or $\mathrm{C}^{\prime}$ ' and $\left.\mathrm{C} 3^{\prime}\right) .{ }^{90}$ Piet Herdewijn and co-workers have examined a series of these compounds ${ }^{91}$ and have concluded that they are too flexible to allow the formation of stable duplexes with a target DNA or RNA. ${ }^{84}$ GNA is the oligomer in which glycol has been used to replace the ribo-sugar, ${ }^{92}$ however this was found not to duplex with RNA, although it did form a strong homo-duplex ${ }^{93}$ (Figure 6).

\section{Covalently linked oligos}

By attaching a specific chemical group to (usually) the 5'-terminus of an oligonucleotide intended for antisense inhibition, researchers have hoped to either increase its efficacy, improve its ability to enter cells, or actually carry out a catalytic reaction. The first known use of a "complementary addressed" oligo to chemically modify a tRNA was from the lab of Dr. D.G. Knorre and V.V. Vlassov. ${ }^{94}$

An acridine ring attached to either end of an oligo can be a reporter group of the environment, both in the isolated oligo (that might form secondary structure) or in the formation of a duplex, where is might interca- 


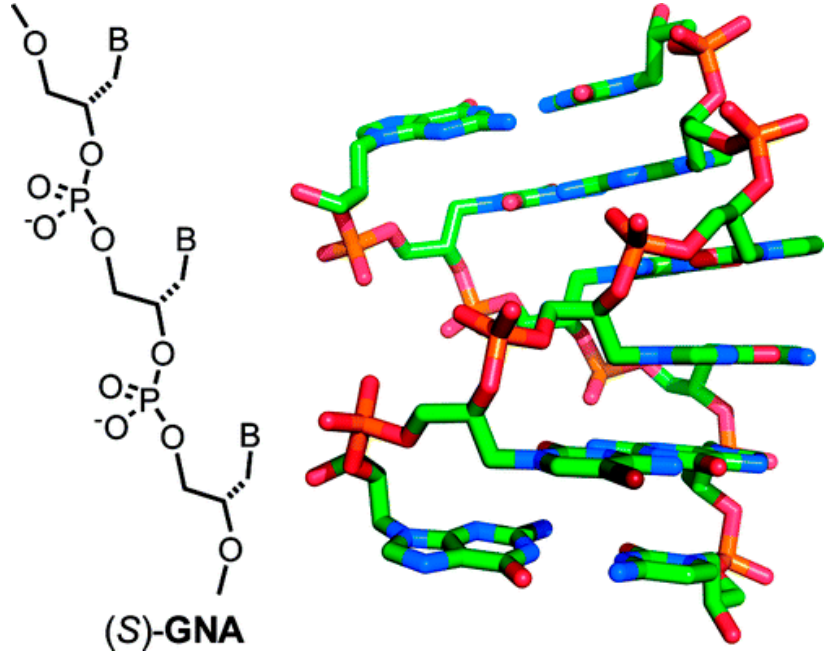

Figure 6. Homo-duplex formed by glycol nucleic acid (GNA). ${ }^{93}$

late between the base pairs. ${ }^{95}$ Fluorescent acridine covalently linked to an oligo was also used to follow cellular uptake. ${ }^{96}$ As well as several passive aromatic groups that can be attached, it is possible to attach reactive groups meant to cleave the RNA in a duplex, groups such as EDTA-Fe(II) $)^{97-99}$ or porphyrin with iron. ${ }^{100}$ Knorre et al. provide an extensive list of such reactive groups. ${ }^{101} \mathrm{We}$ attached imidazole to the terminus of an oligonucleotide $^{102}$ in order to try to reproduce the catalytic effect of RNase, since the catalytic effect depends on imidazoles in the active site. ${ }^{103}$ Since then much progress has been made in synthesizing oligos containing one, ${ }^{104-106}$ two ${ }^{107}$ or multiple imidazole groups ${ }^{108}$ to mimic the catalytic activity of ribonuclease using tRNA as a target. This approach has great potential for site-specific RNA cleavage.

\section{Peptide nucleic acids}

Oligopeptides with nucleic acid bases in place of the usual amino acid side chains have been developed for antisense applications ${ }^{85}$ (Table 3 ). Their advantage is that they are of course resistant to nucleases and are water soluble, and they can easily be attached to cell-penetrating peptides in order to improve cell uptake. ${ }^{109,110} \mathrm{~A}$ variety of biological systems, including bacteria have been targeted successfully with antisense PNAs. ${ }^{111}$

\section{Locked nucleic acids}

Locked Nucleic Acids (LNA) were developed in order to provide an analog completely resistant to nucleases, and by virtue of the locked structure of the sugar moiety (Table 3), reduce the flexibility of the ribo-furanoside ring, thus improving duplex stability. ${ }^{86}$ Kurreck et al compared the LNAs with the PS oligos and found them to be superior, although this does not take into account the cost and difficulty of production. ${ }^{112}$ Another report declared the LNAs were superior to other ASOs. ${ }^{113}$

\section{Morpholino nucleic acids}

Summerton and his co-workers developed the morpholino analog of oligos as a mimic of the natural structure (Table 3), and claim that they are superior to other analogs. ${ }^{87}$ In studies of antisense activity and RNase $\mathrm{H}$ function they claim that the morpholino analog exceeds the function of the PS analog. ${ }^{73,114}$ In a comparison of the PNA, LNA, and morpholino, it was found that each had advantages. ${ }^{115}$ The morpholino analogs have been applied therapeutically in many different biological systems. $^{116}$

\section{Modified RNAs - 2'O substituted analogs}

Researchers realized early on that a potential source of ASOs was the ribo-oligomer with the 2'-hydroxy position substituted with a methyl group or another alkyl group, and this has become a major area of research and development. Sproat and co-workers described the synthesis of 2'O-R analogs, where $\mathrm{R}=\mathrm{Me}$, allyl or dimethylallyl, for antisense applications, primarily because these compounds were relatively easy to synthesize and are resistant to nucleases. ${ }^{117}$ Ohtsuka and co-workers used 2'-O-Me analogs to inhibit the expression of portions of the human $\beta$-globin gene. ${ }^{118}$

Lamond and Sprout expanded on the use of the 2'O-alky-lRNA analogs for applications in RNA biochemistry. ${ }^{119}$

Cook and co-workers described the use of combined 2'O-alkyl ribo- and deoxy- co-polymers and showed that they increased RNase $\mathrm{H}$ activity. ${ }^{120}$ And others combined the PS oligos with 2'O-alkyl co-polymers as improved chimeric antisense analogs. ${ }^{121,122}$ In a comparative study for muscular dystrophy drugs, the 2'OMe-PS combination was found to be more effective in inhibition of exon skipping than other ASOs including LNA and PNA. ${ }^{123}$ This approach of "chimeric" combinations of analogs for improved RNase $\mathrm{H}$ degradation of the mRNA complex was also described by Giles and Tidd. ${ }^{124}$ Eckstein and coworkers described the presence of a 2'-fluoro adenosine in a ribozyme ${ }^{89}$ and Cook and co-workers synthesized uniformly modified 2'-deoxy-2'-fluoro PS oligos as nucle- 
ase-resistant antisense compounds with high affinity and specificity for RNA targets. ${ }^{125}$

This approach was expanded upon by Stan Crooke and those at Ionis (formerly ISIS), who favor 2'O-methoxyethyl substituents (MOE) and 2'4'-constrained ethyl (cET) like the LNA and GalNAC conjugates of ASOs. ${ }^{126}$ Their collaborators at Ciba-Geigy formulated the concept of gapmers as second generation OAS analogs, with the "wings" consisting of 2'O-alkyl PS analogs and the center "gap" consisting of PS oligo only, in order to take advantage of the increased RNase $\mathrm{H}$ activity. ${ }^{127} \mathrm{Of}$ course there are a myriad variations on these themes, but their general conclusion is that the future is with RNA oligo analogs. It should be pointed out, that many of the applications of Crooke and co-workers are targeted not at mRNA per se, but at pre-mRNA before splicing, and at introns or exon-intron junctions. ${ }^{128}$ This provides unique target sequences that prove to be extremely efficient for correcting abnormal gene expression.

\section{OTHER RELATED APPROACHES}

\section{Triple Helix}

The formation of a triple stranded helix with a strand of an oligonucleotide binding into the major groove of the DNA duplex by Hoogsteen base pairing was first shown in $19688^{129}$ (Figure 7).

Dervan and coworkers showed in 1987 that an oligonucleotide with an EDTA-(Fe(II) attached could bind in the major groove of DNA and cause a double strand break. ${ }^{130,131}$ Other workers also added to this approach as a so-called anti-gene strategy. ${ }^{132}$ Hogan and co-workers sought to make triple helix formation an effective gene targeting technique. ${ }^{133}$ Although triple helix formation has continued as an active area of research its therapeutic promise has not been realized.

\section{Aptamers}

Aptamers are oligonucleotides (or peptides) that bind to a specific target molecule and are selected by

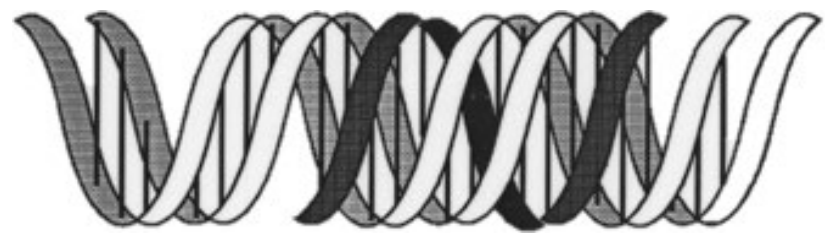

Figure 7. Triple helix showing an oligo (dark) bound in the major groove of DNA. repetition from a large random sequence pool that was first described in 1990. ${ }^{134-136}$ Many applications of this technique were made to evolve oligonucleotides that bind to various biological molecules. ${ }^{137-140}$ Of more recent interesting applications are improvements in the methodology and approaches to therapeutic applications. $^{141-143}$

\section{Ribozymes}

Ribozymes are catalytic RNA molecules that were first described in the early 1980's as the active enzymatic component of RNase P. ${ }^{14-146}$ There are various types of ribozymes that have been characterized from their general shape as hammerhead, pistol, twister and hairpin ribozymes. ${ }^{147}$ Therapeutic applications of ribozymes have been described. ${ }^{148-150}$

\section{Effects of $m R N A$ structure}

In considering the antisense mechanism, one must always bear in mind not only the antisense oligonucleotide analog, but also the mRNA being targeted. It is not enough to know the sequence of the mRNA/DNA, but also its conformation to ensure that the oligo will be able to access a target sense sequence. Studies have been made on the conformation of mRNAs and the access to target sequences. ${ }^{151,152}$ Vlassov and co-workers showed that a binding oligonucleotide can modify and invade the structure of a tRNA target, thus making their use potentially wider. ${ }^{153}$ It has been proposed that a statistical analysis can improve the ability to choose target sequences in mRNA. ${ }^{154}$

\section{Molecular Dynamics Simulations}

Previously we used molecular dynamics (MD) and energy minimization protocols to assess the duplexation of a PS oligo with target complementary RNA in silico. ${ }^{155} \mathrm{MD}$ calculations have also been applied to the PNA analog. ${ }^{156}$ Recently our earlier methodology has been refined and updated ${ }^{157}$ to assess the ability of previously unknown oligo analogs to dimerize with a target RNA. It is not generally realized that there are 10 atoms between one base and the next in DNA (Figure 8), all of which are not required for dimerization to occur in principle.

Of more radically modified analogs that can be conceived with methylene groups in place of the sugar moiety, only one has previously been characterized, namely 


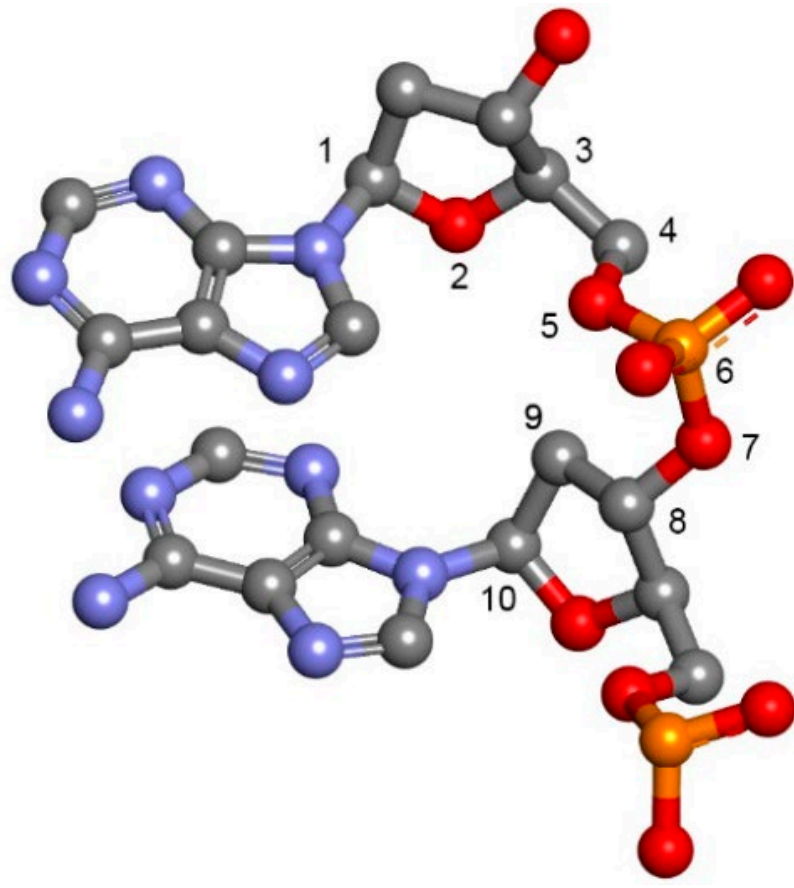

Figure 8. Showing the number of atoms/bonds between adjacent bases in DNA.

GNA. ${ }^{93}$ Recently we have used this MD methodology to assess the capability of other analogs to duplex with complementary DNA and RNA, and we have found that only one of the eight possible structures does in fact form a viable duplex, namely that with the formulation $[-\mathrm{CH}(\mathrm{B})-\mathrm{O}-\mathrm{P}(\mathrm{O})(\mathrm{OH})-\mathrm{O}-\mathrm{CH}(\mathrm{B})-]_{\mathrm{n}}$ with RNA (Figure 9). ${ }^{158}$ This use of computer aided molecular design (CAMD) to guide synthetic strategies is a viable predictive tool in future comparative ASO analog development and rational drug design.

\section{CLINICAL ASPECTS}

Agrawal and coworkers carried out a series of studies on in vivo distribution of various ASOs in animal models. ${ }^{44,159-161}$ In 1998, the first antisense oligonucleotide, Fomivirsen, (Vitravene), a 21-mer PS oligo analog produced by Isis Pharma (now Ionis), was approved by the FDA for human ocular use against cytomegalovirus retinitis in immunocompromised AIDS patients. A detailed review of the recent FDA files ${ }^{162}$ shows that there have been 6 ASOs approved for human use, three of them PS analogs, one a chimeric 2'OMe-PS combination and the two others were of other compositions. Among these drugs approved by the FDA are Nusinersen and Eteplirsen that are exon-skipping antisense oligonucleotides for the treatment of Spinal Muscular Atrophy and Duchenne Muscular Dystrophy. ${ }^{163,164}$

MicroRNA (abbreviated miRNA) are small noncoding RNA molecules (containing about 22 nucleotides) found in animals, plants, and some viruses, that

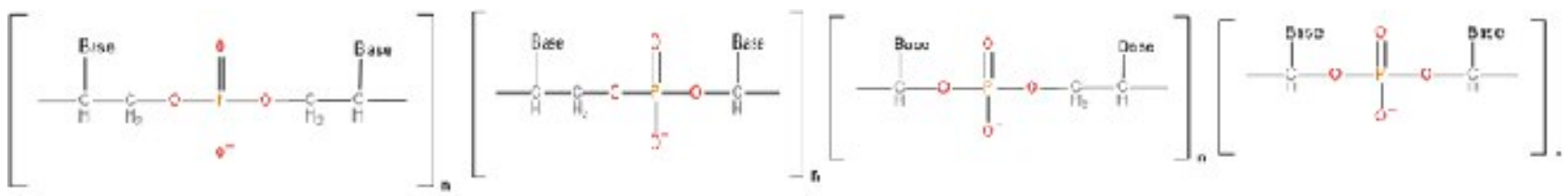
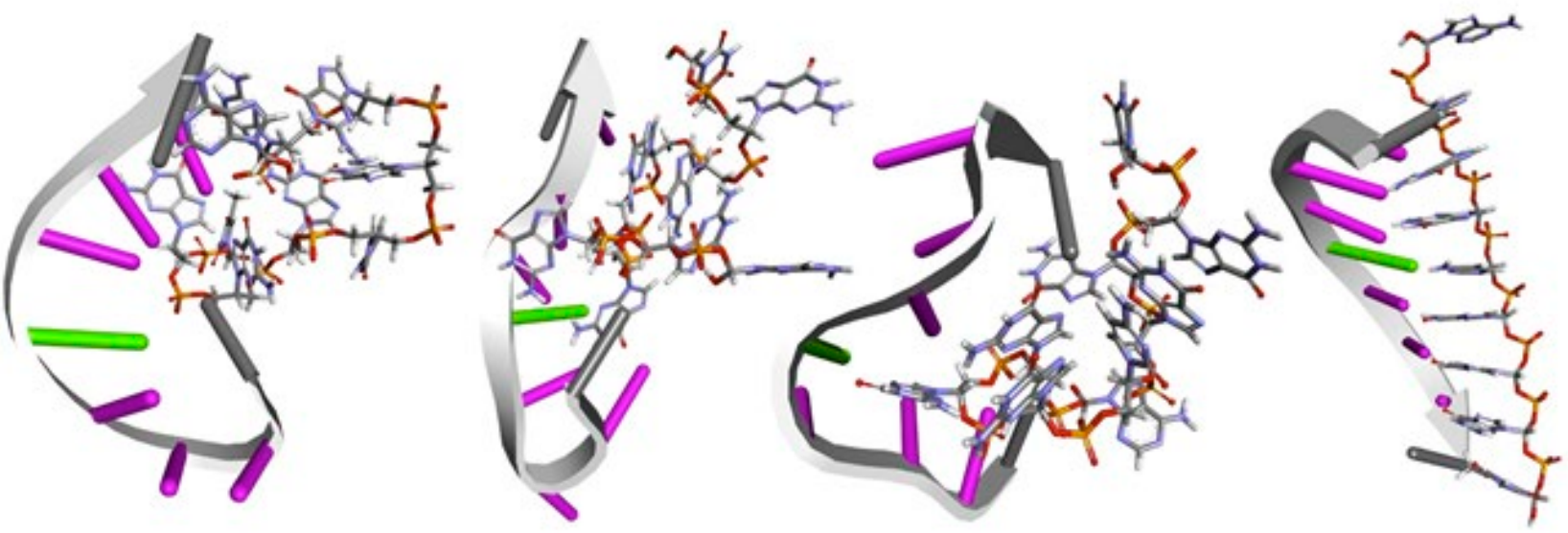

Figure 9. Representative structures from Molecular Dynamics analysis of the most populated cluster for each analog represented above, with complementary RNA. Analysis performed using the entire sampled data. Only one of the four structures with methylene groups in place of the ribo-furanoside forms a stable duplex (on the right). ${ }^{158}$ 
function in RNA silencing and post-transcriptional regulation of gene expression. miRNAs function via basepairing with complementary sequences within mRNA molecules. miRNAs are similar to siRNAs but have different origins and specific functions. miRNAs are associated with many human diseases. miRNAs have been inhibited using locked, morpholino or 2'OMe oligos. ${ }^{165,166}$ This is only the beginning of such inhibitions of miRNAs related to human disease.

In 1998, there were 8 PS-ASOs undergoing clinical trials. ${ }^{46}$ A search of the NIH web-site ClinicalTrials. gov reveals the following interesting results: (a) there are 52 active or completed studies of siRNA; (b) there are 77 active or completed studies of "antisense oligonucleotides" (type not specified; also listed as AS ODNs), the majority in the US, Canada and Europe. It is to be hoped that many more will follow. It is considered possible that mixtures of antisense oligos could be used to target genetically heterogenous diseases such as cancer.

\section{CONCLUSION}

The general conclusion of this article is that the history of this subject really began dramatically with the first publication using the phosphorothioate (PS) analog of oligonucleotides against HIV in $1987 .{ }^{27}$ For the first time this made their development as therapeutic agents feasible. This area of research then expanded rapidly, reached a peak around 2001, during which time many other analogs were developed and applied. Research then declined for two main reasons, first problems that were encountered in the application of the ASO's, such as cell uptake and cost, and secondly the development of endogenous RNAi methods that were considered to be superior. However, like other forms of endogenous biological therapy, such as gene therapy, the promise of siRNA and other techniques have also lost their initial promise. Therapeutic applications of ASO analogs is still a subject with a compelling future.

\section{ACKNOWLEDGEMENTS}

I wish to thank Frank Portugal for reading and commenting on this ms and Gerald Zon for very helpful suggestions. I am grateful to those who worked with me over a period of 34 years on this subject in NCI/NIH, Georgetown Medical School, Sheba Medical Center, Hebrew University and now at Ben Gurion University. I would also like to acknowledge the many colleagues who made significant contributions to this field, namely the late Paul Zamecnik, Samuel Broder, Paul Ts'o, Paul Miller, John Goodchild, the late Dan Brown, Eric Wickstrom, Sudhir Agrawal, Fritz Eckstein, John J. Rossi, Michael Riordan, the late Claude Hélène, Jean-Jacques Toulmé, Michael Hogan, Valentin Vlassov, Jean-Louis Imbach, Piet Herdewijn, Peter Dervan and many others. Herein I have tried to set down the record of the development of this subject as accurately as I could, and any inaccuracy is inadvertent. Note that in writing this article I have generally tried to avoid reference to patents and review articles. I thank Dr. Barak Akabayov for hosting me at Ben Gurion University.

\section{REFERENCES AND NOTES}

1. Jack S. Cohen, Informational drugs: a new concept in pharmacology, in New Leads and Targets in Drug Research, Bezon Fndtn. Symposium, Copenhagen, 1992, Vol. 33, pp. 17-32.

2. Jack S. Cohen, Michael E. Hogan, The New Genetic Medicines, Scientific American 271, 77-82, 1994.

3. Franklin H. Portugal, Jack S. Cohen, A Century of DNA: A history of the discovery of the structure and function of the genetic substance. MIT Press, 1977.

4. Paul C. Zamecnik, Mary L. Stephenson, Inhibition of Rous sarcoma Virus Replication and Cell Transformation by a Specific Oligodeoxynucleotide, Proceedings of the National Academy of Sciences of the United States of America 75, 280-84, 1978.

5. It should be mentioned that there was a prior publication that termed the antisense approach "complementarily addressed" from a group in the USSR, in which they used hexanucleotides attached to reactive groups to bind to and modify specific sites in tRNA. See section on covalently linked nucleic acids.

6. I use the term "oligo" to mean any oligonucleotide and ASO to refer to an antisense oligonucleotide

7. P. S. Eder, R. J. DeVine, J. M. Dagle, J. A. Walder, Substrate specificity and kinetics of degradation of antisense oligonucleotides by a 3' exonuclease in plasma Antisense Research and Development, 141-51, 1991.

8. Reino Heikkila, Gisela Schwab, Eric Wickstrom, Shee Loong Loke, Dov H. Pluznik, Rosemary Watt, Leonard M. Neckers, A c-myc antisense oligodeoxynucleotide inhibits entry into $S$ phase but not progress from G0 to G1, Nature 328, 445-9, 1987.

9. Louis J. Maher, Bruce J. Dolnick, Specific hybridization arrest of dihydrofolate reductase mRNA in vitro using anti-sense RNA or anti-sense oligonucleotides, Archives of Biochemistry and Biophysics 253, 214-20, 1987. 
10. I published a fictionalized account of my experiences in my book "Antisense" in 2014.

11. Cheryl H. Agris, Kathleen R. Blake, Paul S. Miller, M. Parameswara Reddy, Paul O. P. Ts'o, Inhibition of vesicular stomatitis virus protein synthesis and infection by sequence-specific oligodeoxyribonucleoside methylphosphonates, Biochemistry 25, 6268-75, 1986.

12. Paul S. Miller, Cheryl H. Agris, Laure Aurelian, Kathleen R. Blake, Shwu Bin Lin, Akira Murakami, M. Parameswara Reddy, Cynthia Smith, Paul O. P. Ts'o, Control of gene expression by oligonucleoside methylphosphonates, Jerusalem Symposia on Quantum Chemistry and Biochemistry 18, 207-9, 1985.

13. Krishna Jayaraman, Kevin McParland, Paul Miller, Paul O. P. Ts'o, Selective inhibition of Escherichia coli protein synthesis and growth by nonionic oligonucleotides complementary to the 3' end of $16 \mathrm{~S}$ rRNA, Proi. Natl. Acad. Sci. 78, 1537-41, 1981.

14. I had done my $\mathrm{PhD}$ in Cambridge University entitled "The Oxidation of Phosphites" under Michael Blackburn and Lord Todd.

15. My Lab Chief Charles "Snuffy" Myers and my Division Chief Samuel Broder

16. I had met Gerry Zon thru my post-doc Bill Egan, and when I was on sabbatical at the Weizmann Inst., Rehovot, Israel, in 1976-7, I agreed for him to use my laboratory at NIH for their joint research. Later in 1986 we shared a post-doc Kazuo Shinozuka.

17. Marvin H. Caruthers, The Chemical Synthesis of DNA/RNA: Our Gift to Science, J. Biol. Chem. 288, 1420-27, 2013.

18. W. Stec, G. Zon, W. Egan, Automated solid-phase synthesis, separation, and stereochemistry of phosphorothioate analogs of oligodeoxyribonucleotides, $J$. Am. Chem. Soc. 106, 6077-79, 1984.

19. F. Eckstein, H. Gindl, Polyribonucleotides containing a phosphorothioate backbone, Europ. J. biochem. 13, 558-64 1970.

20. S. Spitzer, F. Eckstein, Inhibition of deoxyribonucleases by phosphorothioate groups in oligodeoxyribonucleotides, Nucl. Acids Res. 16, 11691-704, 1988.

21. C. A. Stein, C. Subasinghe, K. Shinozuka, J. S. Cohen, Physicochemical Properties of Phosphorothioate Oligodeoxynucleotides, Nucl. Acids Res. 16, 3209-21, 1988.

22. C. Helene, J-J. Toulme, Control of Gene Expression by Oligodeoxynucleotides Covalently Linked to Intercalating Agents and Nucleic Acid-Cleaving Reagents, in Oligodeoxynucleotides: Antisense Inhibitors of Gene Expression, ed. by J. S. Cohen, Macmillan, 1989.

23. The automated synthesis uses phosphoramidites at the PIII level of oxidation and these give $>99 \%$ yield of joined product and this is then oxidized to phosphate. Sulfurization uses a solution of sulfur instead.

24. M H. Caruthers, S L. Beaucage, C. Becker, J W. Efcavitch, E F. Fisher, G. Galluppi, R. Goldman, P. deHaseth, M. Matteucci, L. McBride, Deoxyoligonucleotide synthesis via the phosphoramidite method, Gene Amplification and Analysis 3, 1-26, 1983.

25. Serge L. Beaucage, Radhakrishnan P. Iyer, Advances in the synthesis of oligonucleotides by the phosphoramidite approach, Tetrahedron 48, 2223-311, 1992.

26. C. Ott, F. Eckstein, Protection of oligonucleotide primers agaisnt degradation by DNA polymerase, Biochemistry 26, 8237-41, 1987.

27. Makoto Matsukura, Kazuo Shinozuka, Gerald Zon, Hiroaki Mitsuya, Marvin Reitz, Jack S. Cohen, Samuel Broder, Phosphorothioate Analogs of Oligodeoxynucleotides: Inhibitors of Replication and Cytopathic Effects of Human Immunodeficiency Virus Proc. Natl. Acad. Sci. 84, 7706-10, 1987.

28. M. Matsukura, G. Zon, K. Shinozuka, M. RobertsGuroff, C. A. Stein, H. Mitsuya, F. Wong-Staal, J. S. Cohen, S. A. Broder, Regulation of Viral Expression of HIV in vitro by Antisense Phosphorothioate Oligodeoxynucleotide against rev, Proc. Natl. Acad. Sci. 86, 4244-48, 1989.

29. Carol Marcus-Sekura, Amy M. Woerner, Kazuo Shinozuka, Gerald Zon, Jr Gerald V. Quinnan, Comparative inhibition of chloramphenicol acetyltransferase gene expression by antisense oligonucleotide analogues having alkyl phosphotriester, methylphosphonate and phosphorothioate linkages, Nucl. Acids Res. 15, 5749-63, 1987.

30. Sudhir Agrawal, John Goodchild, Maria P. Civeira, Arthur H. Thornton, Prem S. Sarin, Paul C. Zamecnik, Oligodeoxynucleoside Phosphoramidates and Phosphorothioates as Inhibitors of Human Immunodeficiency Virus Proc. Natl. Acad. Sci. 85, 7079-83, 1988.

31. D. Kinchington, S. Galpin, J. W. Jaroszewski, K. Ghosh, C. Subasinghe, J. S. Cohen, A comparison of gag, pol and rev antisense oligodeoxynucleotides as inhibitors of HIV-1, Antivir. Res. 17, 53-62, 1992.

32. D. Archambault, C. A. Stein, J. S. Cohen, Phosphorothioate oligonucleotides inhibit the replication of lentiviruses and type $\mathrm{D}$ retroviruses but not that of type C retroviruses, : , , Arch. Virology. 139, 97-109, 1994.

33. S. L. Loke, Zhang, X. H., Stein, C. A., Avigan, M., Cohen, J. S., and Neckers, L. M., Delivery of c-myc antisense phosphorothioate oligodeoxynucleotides to hematapoietic cells in culture by liposome fusion, Curr. Top. Microbiol. Immunol. 141, 282-9, 1988.

34. J. C. Reed, C. A. Stein, C. A. Subasinghe, S. Haldar, C. M. Croce, S. Yum, J. S. Cohen, Antisense-medi- 
ated inhibition of BCL2 proto-oncogene expression and leukemic cell growth; comparisons of phosophorothioate oligonucleotides, Cancer Res. 50, 656570, 1990 .

35. Michael Riordan of Menlo Ventures called me after Makoto Matsukura made our first preserntiaton at a conference in San Franciso and asked to come and see me, and he flew out that night. I recall being telephoned by him later at a restaurant in Chinatown, Washington DC, in 1987 to tell me that he had founded what became Gilead Sciences, now a b\$22 company.

36. I was invited to join several start-up companies, but I became initial scientific adviser to Gilead Sciences and Pharmagenics.

37. The patents were "Inhibitors for the expression of viruses and oncogenes" (NIH: 5,264,423, and $5,276,019,1993)$

38. Conference on "Oligodeoxynucleotides as Antisense Inhibitors of Gene Expression: Therapeutic Implications," Organizing Committee: Jack S. Cohen, James Cradock, Ira Green, George Johnson, Cathy Laughlin, Mace Rothenberg, Nava Sarver, Sheraton Potomac Inn, Rockville MD, June 18-21, 1989

39. This was only the second open meeting held at the formerly closed Soviet city of Akademgorodok in the era of glasnost.

40. Fritz Eckstein, Phosphorothioates, essential components of therapeutic oligonucleotides, Nucleic Acid Therapeutics 24, 374-87, 2014.

41. Jack S. Cohen, Oligodeoxynucleotides: Antisense Inhibitors of Gene Expression. Macmillan, 1989, Topics in Molecular and Structural Biology Vol. 12.

42. M. Ghosh, K. Ghosh, J. S. Cohen, Oligodeoxynucleotide phosphorothioate- phosphodiester co-polymers: assessment for antisense applications, Anticancer Drug Design 8, 15-32, 1993.

43. L. Zhou, M. Morocho, B. C. Chen, J. S. Cohen, Synthesis of phosphorothioate-methylphosphonate oligonucleotide co-polymers, Nucl. Acids Res. 22, 453-56, 1994.

44. S. Agrawal, Z. Jaing, D. Shaw, Q. Cai, A. Roskey, L. Channavajjala, C. Saxinger, R. Zhang, Mixed-backbone oligonucleotides as second generation antisense oligonucleotides: In vitro and in vivo studies, Proc. Natl. Acad. Sci. 94, 2620-25, 1997.

45. Joachim W. Engels, Fritz Eckstein, Antisense Oligonucleotides as Potential Drugs, Reviews in Cell Biology and Molecular Medicine, 2006.

46. James W. Hawkins, A Brief History of Genetic Therapy, Gene Therapy, Antisense Technology and Genomics, in Cinical Trials of Genetic Therapy with
Antisense DNA and DNA Vectors, ed. by E. Wickstrom, Marcel Dekker, 1998, pp. 1-38.

47. D. M. Tidd, P. Hawley, H. M. Warenius, I. Gibson, Evaluation of $\mathrm{N}$-ras oncogene anti-sense, sense and nonsense sequence methylphosphonate oligonucleotide analogs Anti-Cancer Drug Design 3, 117-27, 1988.

48. F. Morvan, B. Rayner, J-L. Imbach, S. Thenet, J.R. Bertrand, J. Paoletti, C. Malvy, C. Paoletti, Synthesis of unnatural a-anomeric oligodeoxyribonucleotides containing the four usual bases and study of their suibstrate activities for nucleases, Nucl. Acids Res. 15, 3421-37, 1987.

49. B. Rayner, M. Matsukura, F. Morvan, J.S. Cohen, J.-L Imbach, Activite anti-VIH in vitro doligodesoxynucleotides phosphorothioates d'anomerie alpha, C.R. Acad. Sci. Paris 310, 61-64, 1990.

50. K. Mori, C. Boizeau, C. Cazenave, M. Matsukura, Subasinghe, C, J. S. Cohen, J. J. Toulme, C. A. Stein, Phosphoroselenoate oligodeoxynucleotides: synthesis, physico-chemical characterization, anti-sense inhibitory properties and anti-HIV activity, Nucl. Acids. Res 17, 8207-19, 1989.

51. P S. Miller, J C. Barrett, P O. P. Ts'o, Synthesis of oligodeoxyribonucleotide ethyl phosphotriesters and their specific complex formation with transfer ribonucleic acid, Biochemistry 13, 4887-96, 1974.

52. J. W. Jaroszewski, V. Clausen, J. S Cohen, O. Dahl, NMR investigations of duplex stability of phosphorothioate and phosphorodithioate DNA analogues modified in both strands, Nucl. Acids Res. 24, 829-34, 1996.

53. Suzanne Peyrottes, Jean-Jacques Vasseur, Jean-Louis Imbach, Bernard Rayner, Oligodeoxynucleoside phosphoramidates (P-NH2): synthesis and thermal stability of duplexes with DNA and RNA targets, Nucl. Acids Res. 24, 1841-48 1996.

54. J. W. Jaroszewski, J. S. Cohen, Cellular Uptake of Antisense Oligodeoxynucletides., in Advanced Drug Delivery Reviews, ed. by R. L. Juliano, 1991, pp. 23550.

55. V. Meidan, J. S. Cohen, N Amariglio, D. Hirsch-Lerner, Y. and Barenholz, Interaction of oligonucleotides with cationic lipids: the relationship between electrostatics, hydration and state of aggregation, Biochim. Biophys. Acta. 1464, 251-61, 2000.

56. V. Meidan, J. Glazer, Amariglio, N., J. Cohen, Y. Barenholz, Oligonucleotide lipoplexes: the influence of oligonucleotide composition on complexation, Biochim Biophys Acta. 1568, 177-82, 2001.

57. V. Meidan, J. Glazer, S. Salomon, Y. Sidi, Y. Barenholz, J. S. Cohen, G. Lilling, Antisense against Bcl-2 
in breast cancer cells: A systematic comparison of different lipoplexes, J. Liposome Res. 16, 27-43, 2006.

58. Michael J. Gait, Peptide-mediated cellular delivery of antisense oligonucleotides and their analogues, Cellular and Molecular Life Sciences 60, 844-53, 2003.

59. Nathaniel L. Rosi, David A. Giljohann, C. Shad Thaxton, Abigail K. R. Lytton-Jean, Min Su Han, Chad A. Mirkin, Oligonucleotide-Modified Gold Nanoparticles for Intracellular Gene Regulation, Science, 102730, 2006.

60. S. Akhtar, (ed.), Delivery strategies for antisense oligonucleotide therapeutics. CRC Press, 1995/2017.

61. Stanley T. Crooke, Shiyu Wang, Timothy A. Vickers, Wen Shen, Xue-Hai Liang, Cellular uptake and trafficking of antisense oligonucleotides, Nature biotechnology 35, 230-37, 2017.

62. Radhakrishnan P. Lyer, Bogdan Uznanski, Jila Boal, Christy Storm, William Egan, Makoto Matsukura, Samue Broder, Gerald Zon, Andrzej Wilk, Abasic oligodeoxyribonucleoside phosphorothioates: synthesis and evaluation as anti-HIV-1 agents $\mathrm{Nucl}$, Acids Res. 18, 2855-59, 1990.

63. W. Gao, J. W. Jaroszewski, J. S. Cohen, Y.-C. Cheng, Mechanisms of inhibition of herpes simplex virus type 2 growth by 28 -mer phosphorothioate oligodeoxycytidine, J. Biol. Chem. 33, 20172-178 1990.

64. K. B. Spurgers, C. M. Sharkey, K. L. Warfield, S. Bavari, Oligonucleotide antiviral therapeutics: Antisense and RNA interference for highly pathogenic RNA viruses, Antiviral Research 78, 26-36, 2008,.

65. Chiara Brignole, Fabio Pastorino, Danilo Marimpietri, Gabriella Pagnan, Angela Pistorio, Theresa M. Allen, Vito Pistoia, Mirco Ponzoni, Immune CellMediated Antitumor Activities of GD2-Targeted Liposomal c-myb Antisense Oligonucleotides Containing CpG Motifs, Journal of the National Cancer Institute 96, 1171-80 2004.

66. Volker Wacheck, Clemens Krepler, Sabine Strommer, Elisabeth Heere-Ress, Robert Klem, Hubert Pehamberger, Hans-Georg Eichler, Burkhard Jansen, Antitumor effect of G3139 Bcl-2 antisense oligonucleotide is independent of its immune stimulation by $\mathrm{CpG}$ motifs in SCID mice, Antisense \& Nucleic Acid Drug Development 12, 359-67 2002.

67. Husam S. Younis, Tim Vickers, Arthur A. Levin, Scott P. Henry, CpG and non-CpG oligodeoxynucleotides induce differential proinflammatory gene expression profiles in liver and peripheral blood leukocytes in mice, Journal of Immunotoxicology 3, 57-68 2006.

68. John M. Dagle, Joseph A. Walder, Daniel L. Weeks, Targeted degradation of mRNA in Xenopus oocytes and embryos directed by modified oligonucleotides: studies of An2 and cyclin in embryogenesis, Nucl. Acids Res. 18, 4751-57, 1990.

69. R Y Walder, J A Walder, Role of RNase H in hybridarrested translation by antisense oligonucleotides, Proc. Natl. Acad. Sci. Jul; (14): 85, 5011-15, 1988.

70. S. Agrawal, S.H. Mayrand, P.C. Zamecnik, T. Pederson, Site-specific excision from RNA by RNase $\mathrm{H}$ and mixed-phosphate backbone oligodeoxynucletides, Proc. Natl. Acad. Sci. 87, 1401-5, 1990.

71. Gareth J. Veal, Sudhir Agrawal, Randal A. Byrn, Sequence-specific RNase H cleavage of gag mRNA from HIV-1 infected cells by an antisense oligonucleotide in vitro, Nucl. Acids Res. 26, 5670-75, 1998.

72. Wen Yi Gao, Fu Sheng Han, Christy Storm, William Egan, Yung Chi Cheng, Phosphorothioate oligonucleotides are inhibitors of human DNA polymerases and RNase $\mathrm{H}$ : Implications for antisense technology, Molecular Pharmacology 41, 223-29, 1992.

73. J. Summerton, Morpholino antisense oligomers: the case for an RNase $\mathrm{H}$-independent structural type, Biochimica et Biophysica Acta, Gene Structure and Expression 1489, 141-58, 1999.

74. Karen L. Fearon, Bernard L. Hirschbein, Choi-Ying Chiu, Maria R. Quijano, Gerald Zon, Phosphorothioate oligodeoxynucleotides: large-scale synthesis and analysis, impurity characterization, and the effects of phosphorus stereochemistry, Ciba Foundation Symposium 209, 19-37, 1997.

75. Ilyas M. Khan, Judy M. Coulson, A novel method to stabilize antisense oligonucleotides against exonuclease degradation, Nucl. Acids Res. 21, 2957-8, 1993.

76. Grzegorz Rebowski, Marzena Wojcik, Malgorzata Boczkowska, Edyta Gendaszewska, Miroslaw Soszynski, Grzegorz Bartosz, Wojciech Niewiarowski, Antisense hairpin loop oligonucleotides as inhibitors of expression of multidrug resistance-associated protein 1: their stability in fetal calf serum and human plasma, Acta Biochimica Polonica 48, 1061-76, 2001.

77. A. Fire, S. Xu, MK. Montgomery, SA. Kostas, Se. Driver, CC. Mello, Potent and specific genetic interference by double-stranded RNA in Caenorhabditis elegans, Nature 391, 806-11, 1998.

78. P. D. Zamore, T. Tuschi, P.A. Sharp, D Bartel, P, RNAi: Double stranded RNA directs the ATPdependent cleavage of mRNA at 21-23 nucleotide intervals, Cell 101, 25-53, 2000.

79. Y. Dorsett, T. Tuschi, siRNAs: Applications in functional genomics and potential as therapeutics, Natrure Reviews 3, 318-29, 2004.

80. Mark A. Behlke, Chemical Modification of siRNAs for In Vivo Use, Oligonucleotides 18, 305-20, 2008. 
81. R. Titze-de-Almeida, C. David, S.S. Titze-de-Almeida, The Race of 10 Synthetic RNAi-Based Drugs to the Pharmaceutical Market, Pharm. Res. 34, 1339-63, 2017.

82. GF. Deleavey, JK. Watts, T. Alain, Synergistic effects between analogs of DNA and RNA inprove the potency of si-RNA mediated gene silencing, Nucl. Acids Res. 38, 4547-57, 2010.

83. Guihua Sun, John J. Rossi, Problems associated with reporter assays in RNAi studies, RNA Biology 6, 40611, 2009.

84. Frank Vandendriessche, Koen Augustyns, Van Aerschot, Roger Busson, Jos Hoogmartens, Piet Herdewijn, Acyclic oligonucleotides: possibilities and limitations, Tetrahedron 49, 7223-38, 1993.

85. Michael Egholm, Ole Buchardt, Peter E. Nielsen, Rolf H. Berg, Peptide nucleic acids (PNA). Oligonucleotide analogs with an achiral peptide backbone, J. Am. Chem. Soc. 224, 1895-7, 1992.

86. Jesper Wengel, Alexei Koshkin, Sanjay K Singh, Poul Nielsen, Michael Meldgaard, Vivek K. Rajwanshi, Ravindra Kumar, Jan Skouv, Christina B Nielsen, Jens Peter Jacobsen, LNA (Locked Nucleic Acid), Nucleosides \& Nucleotides 18, 1365-70, 1999.

87. J Summerton, D. Weller, Morpholino antisense oligomers: design, preparation, and properties, Antisense \& Nucleic Acid Drug Development 7, 187-95, 1997.

88. E; Wagner, B Oberhauser, A Holzner, H Brunar, G Issakides, G Schaffner, M Cotten, M Knollmüller, C R. Noe, A simple procedure for the preparation of protected 2'-O-methyl or 2'-O-ethyl ribonucleoside3'-O-phosphoramidites, Nucl. Acids Res. 19, 5965-71, 1991.

89. David B. Olsen, Fritz Benseler, Helle Aurup, Wolfgang A. Pieken, Fritz Eckstein, Study of a hammerhead ribozyme containing 2'-modified adenosine residues, Biochemistry 30, 9735-41, 1991.

90. Yves Merle, Eric Bonneil, Liliane Merle, Janos Sagi, Attila Szemzo, Acyclic oligonucleotide analogs, International Journal of Biological Macromolecules 17, 23946, 1995.

91. K. Augustyns, J. Rozenski, A. Van Aerschot, G. Janssen, P. Herdewijn, Synthesis of 2,4-dideoxy-.beta.-Derythro-hexopyranosyl nucleosides, J. Org. Chem. 58, 2977-82, 1991.

92. E. Meggers, L. Zhang, Synthesis and properties of the simplified nucleic acid glycol nucleic acid, Accts. Chem. Res. 43, 1092-102, 2010.

93. AT. Johnson, MK. Schlegel, E. Meggers, LO. Essen, O. Wiest, On the structure and dynamics of duplex GNA, J. Org. Chem., 7964-74, 2011.
94. N. I. Grineva, G. G Karpova, Complementarily addressed modification of rRNA with p-(chloroethylmethylamino)benzylidene hexanucleotides, FEBS Letters 32, 351-5, 1973.

95. U. Asseline, M. Delarue, G. Lancelot, J-J. Toulme, N.T. Thuong, T. Montenay-Garestier, C. Helene, Nucleic acid-binding moleculares with high affinity and base sequence specificity: Intercalating agents covalently linked to oligodeoxynucleotides, Proc. Natl. Acad. Sci. 81, 3297-301, 1984.

96. C. A. Stein, K. Mori, S. L. Loke, C. Subasinghe, K. Shinozuka, J. S. Cohen, L. M. Neckers, Phosphorothioate and Normal Oligodeoxynucleotides with 5'-linked Acridine: Characterization and Preliminary Kinetics of Cellular Uptake, Gene 72, 333-41, 1988.

97. A.S. Boutorin, V.V. Vlassov, S.A. Kazakov, I.V. Kutiavin, M.A. Podyminogin, Complementary addressed reagents carrying EDTA-Fe(II) groups for drected cleavage of single-stranded nucleic acids, FEBS Letters 172, 43-46, 1984.

98. B.C.F. Chu, L.E. Orgel, Nonenzymatic sequencespecific cleavage of single-stranded DNA, Proc. Natl. Acad. Sci. 82, 963-67, 1985.

99. G.B Dreyer, P.B. Dervan, Sequence-specific cleavage of single stranded DNA: OligodeoxynucleotidesEDTA-Fe(II), Proc. Natl. Acad. Sci. 82, 968-72, 1985.

100.T. Le Doan, L. Perroualt, M. Chassignol, N.T Thuong, C. Hele3ne, Sequence-targeted chemical modifications of nucleic acids by complementary oligonucleotides covalently liked to porphyrin, $\mathrm{Nucl}$. Acids Res. 15, 8643-59, 1987.

101.D.G. Knorre, V.V. Vlassov, V.F. Zarytova, Oligodeoxynucleotides linked to reactive groups, in Oligodeoxynucleotides, ed. by J. S. Cohen, Macmillan, 1989, pp. 173-96.

102.N. N. Polushin, B.-C. Chen, L. W. Anderson, J. S. Cohen, Synthesis and characterization of imidazoyllinked synthons and 3'-conjugated thymidine derivatives, J. Org. Chem. 58, 4606-13,, 1993.

103.G. C. K. Roberts, E. A. Dennis, D. H. Meadows, J. S. Cohen, O. Jardetzky, The Mechanism of Action of Ribonuclease, Proc. Natl. Acad. Sci. USA 62, 1151-8, 1969.

104.M. Beban, P. S. Miller, Preparation of an imidazoleconjugated oligonucleotide, Bioconjug. Chem 11, 599603, 2000.

105.N. G. Beloglazova, V. N. Sil'nikov, M. A. Zenkova, V. V. Vlassov, Cleavage of yeast tRNAPhe with complementary oligonucleotide conjugated to a small ribonuclease mimic, FEBS Letters 481, 277-80, 2000.

106.K. Ushijima, H. Gouzu, K. Hosono, M. Shirakawa, K. Kagosima, K. Takai, H. Takaku, Site-specific cleavage 
of tRNA by imidazole and/or primary amine groups bound at the 5'-end of oligodeoxyribonucleotides, Biochim Biophys Acta. 1379, 217-23, 1998.

107.N. G. Beloglazova, M. M. Fabani, M. A. Zenkova, E. V. Bichenkova, N. N. Polushin, V. V. Sil'nikov, K. T. Douglas, V. V. Vlassov, Sequence-specific artificial ribonucleases. I. Bis-imidazole-containing oligonucleotide conjugates prepared using precursor-based strategy, Nucleic Acids Research 32, 3887-97, 2004.

108.N. G. Beloglazova, M. M. Fabani, N. N. Polushin, V. V. Sil'nikov, V. V. Vlassov, E. V. Bichenkova, M. A. Zenkova, Site-Selective Artificial Ribonucleases: Oligonucleotide Conjugates Containing Multiple Imidazole Residues in the Catalytic Domain, Journal of Nucleic Acids, Article ID 748632, 2011.

109.M. Mondhe, A. Chessher, S. Goh, L. Good, J.E.M. Stach, Species-Selective Killing of Bacteria by Antimicrobial Peptide-PNAs., Plos One 9, e89082, 2014.

110.N. Patenge, R. Pappesch, F. Krawack, C. Walda, M. Abu Mraheil, A. Jacob, T. Hain, B. Kreikemeyer, Inhibition of Growth and Gene Expression by PNApeptide Conjugates in Streptococcus pyogenes, Mol. Therapy-Nucl. Acids 2, e132, 2013.

111. Natalia Nekhotiaeva, Satish Kumar Awasthi, Peter E. Nielsen, Liam Good, Inhibition of Staphylococcus aureus gene expression and growth using antisense peptide nucleic acids, Molecular Therapy 10, 652-59 2004.

112.Jens Kurreck, Eliza Wyszko, Clemens Gillen, Volker A. Erdmann, Design of antisense oligonucleotides stabilized by locked nucleic acids, Nucl. Acids Res. 30, 1911-18, 2002.

113.Claes Wahlestedt, Peter Salmi, Liam Good, Johanna Kela, Thomas Johnsson, Tomas Hokfelt, Christian Broberger, Frank Porreca, Josephine Lai, Kunkun Ren, Potent and nontoxic antisense oligonucleotides containing locked nucleic acids, Proceedings of the National Academy of Sciences of the United States of America 97, 5633-38, 2000.

114.James Summerton, David Stein, Sung Ben Huang, Paula Matthews, Swight Weller, Michael Partridge, Morpholino and phosphorothioate antisense oligomers compared in cell-free and in-cell systems, Antisense \& Nucleic Acid Drug Development 7, 63-70 1997.

115.Shantanu Karkare, Deepak Bhatnagar, Promising nucleic acid analogs and mimics: characteristic features and applications of PNA, LNA, and morpholino, Applied Microbiology and Biotechnology 71, 575862006.

116.B. W. Neuman, D. A. Stein, A. D. Kroeker, M.J. Churchill, A. M. Kim, P. Kuhn, P. Dawson, H. M.
Moulton, R. K. Bestwick, P. L. Iversen, Inhibition, escape, and attenuated growth of severe acute respiratory syndrome coronavirus treated with antisense morpholino oligomers, Journal of virology 79, 9665762005.

117.A. M. Iribarren, B. S. Sproat, P. Neuner, I. Sulston, U. Ryder, A. I. Lamond, 2'-O-alkyl oligoribonucleotides as antisense probes, Proc. Natl. Acad. Sci. 87, 774751, 1990.

118.Akila Mayeda, Yoji Hayase, Hideo Inoue, Eiko Ohtsuka, Yasumi Ohshima, Surveying Cis-Acting Sequences of Pre-mRNA by Adding Antisense 2'-O-Methyl Oligoribonucleotides to a Splicing Reaction, The Journal of Biochemistry 108, 399-405, 1990,.

119.A I. Lamond, B S. Sproat, Antisense oligonucleotides made of 2'-O-alkylRNA: their properties and applications in RNA biochemistry, FEBS letters 325, 123-7, 1993.

120.Brett P. Monia, Elena A.; Gonzalez Lesnik, Carolyn, Walt F. Lima, Danny McGee, Charles J. Guinosso, Andrew M. Kawasaki, P. Dan Cook, Susan M Freier, Evaluation of 2'-modified oligonucleotides containing 2 '-deoxy gaps as antisense inhibitors of gene expression, J. Biol. Chem. 268, 14514-22, 1993.

121.Valeri Metelev, Julianna Lisziewicz, Sudhir Agrawal, Study of antisense oligonucleotide phosphorothioates containing segments of oligodeoxynucleotides and 2'-O-methyloligoribonucleotides, Bioorganic \& Medicinal Chemistry Letters 4, 2929-34, 1994.

122. Byong Hoon Yoo, Elena Bochkareva, Alexey Bochkarev, Tung-Chung Mou, Donald M Gray, 2'-O-methylmodified phosphorothioate antisense oligonucleotides have reduced non-specific effects in vitro, $\mathrm{Nucl}$. Acids Res. 32, 2008-16 2004.

123.A. Artsma-Rus, W.E. Kaman, M. Bremer-Bout, A. A. Janson, J. T. den Dunnan, G .J. van Ommen, J. C. van Deutekom, Comparative analysis of antisense oligonucletide analogs for targeted DMD exon 46 skipping in muscle cells, Gene Therapy 11, 1391-8, 2004.

124.Richard V. Giles, David M. Tidd, Enhanced RNase H activity with methylphosphonodiester/phosphodiester chimeric antisense oligodeoxynucleotides, AntiCancer Drug Design 7, 37-48, 1992.

125.A M Kawasaki, M D Casper, S M Freier, E A Lesnik, M C Zounes, L L Cummins, C Gonzalez, P D Cook, Uniformly modified 2'-deoxy-2'-fluoro phosphorothioate oligonucleotides as nuclease-resistant antisense compounds with high affinity and specificity for RNA targets, Journal of Medicinal Chemistry 36, 831-41, 1993.

126.A. Robert MacLeod, Stanley T. Crooke, RNA Therapeutics in Oncology: Advances, Challenges, and 
Future Directions, The Journal of Clinical Pharmacology 57, S43-S59, 2017.

127.K.-H. Altmann, D. Fabbrot, N. M. Dean, T. Geigert, 6. P. Mania, M. Mullert, P. Nickling, Second-generation antisense oligonucleotides: structure-activity relationships and the design of improved signaltransduction inhibitors, Biochemical Society Transactions 24, 630-37, 1996.

128.C. Frank Bennett, Stanley T. Crooke, Muthiah Manoharan, et al., Alteration of cellular behavior by antisense modulation of mRNA processing, United States Patent, US20020049173 2002.

129.A. R. Morgan, R. D. Wells, Specificity of the threestranded complex formation between double-stranded DNA and single-stranded RNA containing repeating nucleotide sequences, Journal of Molecular Biology 37, 63-80, 1968.

130.L. J. Maher, B. Wold, P. B. Dervan, Oligonucleotidedirected DNA triple-helix formation: an approach to artificial repressors?, Antisense research and development 1, 277-81, 1991.

131.H. E. Moser, P. B. Dervan, Sequence-specific cleavage of double helical DNA by triple helix formation, $\mathrm{Sci}$ ence 238, 645-50 1987.

132.C. Helene, The Anti-Gene Strategy: control of gene expression by triplex-forming oligonucleotides, Anticancer Drug Design 6, 569-84, 1991.

133. Karen M. Vasquez, Theodore G. Wensel, Michael E. Hogan, John H. Wilson, High-Affinity Triple Helix Formation by Synthetic Oligonucleotides at a Site within a Selectable Mammalian Gene, Biochemistry 34, 7243-51 1995.

134.John Abelson, Directed evolution of nucleic acids by independent replication and selection, Science 249, 488-9, 1990.

135. Andrew D. Ellington, Jack W. Szostak, In vitro selection of RNA molecules that bind specific ligands, Nature 346, 818-22 1990.

136.Craig Tuerk, Larry Gold, Systematic evolution of ligands by exponential enrichment: RNA ligands to bacteriophage T4 DNA polymerase, Science 249, 50510, 1990.

137.Petra Burgstaller, Michael Famulok, Isolation of RNA aptamers for biological cofactors by in vitro selection, Angew. Chem., Int. Ed. Engl. 33, 1084-7, 1994.

138. Rick Conrad, Lisa M. Keranen, Andrew D. Ellington, Alexandra C. Newton, Isoenzyme-specific inhibition of protein kinase C by RNA aptamers, J. Biol. Chem. 269, 32051-4, 1994.

139.D. E. Huizenga, J. W. Szostak, A DNA aptamer that binds adenosine and ATP, Biochemistry 34, 656-65, 1995.
140.Roman F. Macaya, Peter Schultze, Flint W. Smith, James A. Roe, Juli Feigon, Thrombin-binding DNA aptamer forms a unimolecular quadruplex structure in solution, Proc. Natl. Acad. Sci. 90, 3745-9, 1993.

141.M. L. Andreola, C. Calmels, J. Michel, J. J. Toulmé, S. Litvak, Towards the selection of phosphorothioate aptamers optimizing in vitro selection steps with phosphorothioate nucleotides, Europ. J. Biochem. 267, 5032-40, 2000.

142.C. Boiziau, J. J. Toulmé, A method to select chemically modified aptamers directly, Antisense \& Nucleic Acid Drug Development 11, 379-85, 2001.

143.Joon-Hwa Lee, Marella D. Canny, Andrea De Erkenez, Dominik Krilleke, Yin-Shan Ng, David T.. Shima, Arthur Pardi, Fiona Jucker, A therapeutic aptamer inhibits angiogenesis by specifically targeting the heparin binding domain of VEGF165, Proc. Natl. Acad. Sci. 102, 18902-07 2005.

144.Brenda L. Bass, Thomas R. Cech, Specific interaction between the self-splicing RNA of Tetrahymena and its guanosine substrate: implications for biological catalysis by RNA, Nature 308, 820-6, 1984.

145.Cecilia Guerrier-Takada, Katheleen Gardiner, Terry Marsh, Norman Pace, Sidney Altman, The RNA moiety of ribonuclease $\mathrm{P}$ is the catalytic subunit of the enzyme, Cell 35, 849-57, 1983.

146.K. Kruger, P.J. Grabowski, A.J. Zaug, J. Sands, D.E. Gottschling, T.R. Cech, Self-splicing RNA: autoexcision and autocyclization of the ribosomal RNA intervening sequence of Tetrahymena, Cell 31 147-57, 1982.

147.M.J. Fedor, J.R. Williamson, The catalytic diversity of RNAs, Nature Reviews Molecular Cell Biology 6 399412, 2005.

148.Sidney Altman, RNA enzyme-directed gene therapy, Proc. Natl. Acad. Sci. 90, 10898-900, 1993.

149.David J. Earnshaw, Michael J. Gait, Progress toward the structure and therapeutic use of the hairpin ribozyme, Antisense \& Nucleic Acid Drug Development 7, 403-11, 1997.

150.A. Thybusch-Bernhardt, A. Aigner, S. Beckmann, F. Czubayko, H. Juhl, Ribozyme targeting of HER-2 inhibits pancreatic cancer cell growth in vivo, European Journal of Cancer 37, 1688-94, 2001.

151.J. Jaroszewski, J.L. Syi, M. Ghosh, K. Ghosh, J. S. Cohen, Targeting of antisense DNA: comparison of activity of anti-rabbit b-globin phosphorothioate oligodeoxynucleotides with computer predictions of mRNA folding, Antisense Res. Devel. 3, 339-48, 1993.

152.Philippe Verspieren, Nadine Loreau, Nguyen Thanh Thuong, David Shire, Jean Jacques Toulme, Effect of RNA secondary structure and modified bases on the 
inhibition of trypanosomatid protein synthesis in cell free extracts by antisense oligodeoxynucleotides, Nucleic Acids Research 18, 4711-17, 1990.

153. Vladislav A. Petyuk, Marina A. Zenkova, Richard Giege, Valentin V Vlassov, Hybridization of antisense oligonucleotides with the 3' part of tRNAPhe, FEBS Letters 444, 217-21, 1999.

154.Ye Ding, Charles E. Lawrence, A statistical sampling algorithm for RNA secondary structure prediction, Nucl. Acids Res. 31, 7280-301 2003.

155.J. W. Jaroszewski, J.-L. Syi, J. Maizel, J. S. Cohen, Towards rational design of antisense DNA: molecular modeling of phosphorothioate DNA analogues, Anticancer Drug Design 7, 253-62, 1992.

156.R. Soliva, E. Sherer, F.J. Luque, C.A. Laughton, M. Orozco, Molecular Dynamics Simulations of PNA.DNA and PNA.RNA Duplexes in Aqueous Solution J. Am. Chem. Soc. 122,, 5997-6008, 2000.

157.R. Galindo-Murillo, D.R. Roe, T.E.I. Cheatham, Convergence and reproducibility in molecular dynamics simulations of the DNA duplex d(GCACGAACGAACGAACGC), Biochim. et Biophys. Acta (General Subjects) 1850,, 1041-58, 2015.

158.Rodrigo Galindo-Murillo, Barak Akabayov, Jack S. Cohen, Molecular Dynamics Simulations of Duplexation of Acyclic Analogs of Nucleic Acids for Antisense Inhibition, Molec. Therap. - Nucl. Acids 23, 527535, 2021.

159.Hui Wang, Jie Hang, Zhenqi Shi, Mao Li, Dong Yu, Ekambar R Kandimalla, Sudhir Agrawal, Ruiwen Zhang, Antisense oligonucleotide targeted to RIalpha subunit of cAMP-dependent protein kinase (GEM231) enhances therapeutic effectiveness of cancer chemotherapeutic agent irinotecan in nude mice bearing human cancer xenografts: in vivo synergistic activity, pharmacokinetics and host toxicity, International Journal of Oncology 21, 73-80, 2002.

160.Ruiwen Zhang, Hui Wang, Sudhir Agrawal, Novel antisense anti-MDM2 mixed-backbone oligonucleotides: proof of principle, in vitro and in vivo activities, and mechanisms Current Cancer Drug Targets 5, 43-49, 2005.

161.Xin-xia Zhang, Chang-cong Cui, Xiang-guang Xu, Xue-song Hu, Wei-hua Fang, Bi-juan Kuang, In vivo distribution of c-myc antisense oligodeoxynucleotides local delivered by gelatin-coated platinum-iridium stents in rabbits and its effect on apoptosis, Chinese Medical Journal (English Edition) 117, 258-63, 2004.

162.Jacqueline Ruger, Silvia Ioannou, Daniela Castanotto, Cy A. Stein, Oligonucleotides to the (Gene) Rescue: FDA Approvals 2017-2019, Trends in Pharmacological Sciences 41, 27-41, 2020.
163.Annemieke Aartsma-Rus, FDA Approval of Nusinersen for Spinal Muscular Atrophy Makes 2016 the Year of Splice Modulating Oligonucleotides Nucleic Acid Therapeutics 27, 67-69, 2017.

164.Matthias Boentert, Stephan Wenninger, Valeria A. Sansone, Respiratory involvement in neuromuscular disorders, Current Opinion in Neurology 30, 529-37, 2017.

165.W.P. Kloosterman, A.K. Lagendijk, R.F. Ketting, J.D. Moulton, R.H. Plasterk, Targeted inhibition of miRNA maturation with morpholinos reveals a role for miR-375 in pancreatic islet development, PLOS Biology 5, e203, 2007.

166.G. Meister, M. Landthaler, Y. Dorsett, T. Tuschl, Sequence-specific inhibition of microRNA- and siRNA-induced RNA silencing, RNA Biology 10 544-50, 2004. 